\title{
ASSESSING THE EFFECTIVENESS OF EMBEDDING CFRP LAMINATES IN THE NEAR SURFACE FOR STRUCTURAL STRENGTHENING
}

\author{
Joaquim A. O. Barros ${ }^{*}$, Débora R. S. M. Ferreira ${ }^{\S}$, Adriano S. Fortes ${ }^{\S}$, Salvador J. E. Dias ${ }^{\S}$
}

\begin{abstract}
*Assistant Professor, Dep. of Civil Eng., University of Minho, Campus de Azurém, 4800-058 Guimarães Portugal
${ }^{\S}$ PhD Student, Dep. of Civil Eng., University of Minho, Campus de Azurém, 4800-058 Guimarães Portugal
\end{abstract}

\begin{abstract}
Near Surface Mounted (NSM) is a recent strengthening technique based on bonding Carbon Fiber Reinforced Polymer (CFRP) bars (rods or laminate strips) into pre-cut grooves on the concrete cover of the elements to strength. To assess the effectiveness of the NSM technique, an experimental program is carried out involving reinforced concrete (RC) columns, RC beams and masonry panels. In columns failing in bending the present work shows that the failure strain of the (CFRP) laminates can be attained using the NSM technique. Beams failing in bending are also strengthened with CFRP laminates in order to double their load carrying capacity. This goal was attained and maximum strain levels of about $90 \%$ of the CFRP failure strain were recorded in this composite material, revealing that the NSM technique is also very effective to increase the flexural resistance of RC beams.

The effectiveness of externally bonded reinforcing (EBR) and NSM techniques to increase the flexural resistance of masonry panels is also assessed. In the EBR technique the CFRP laminates are externally bonded to the concrete joints of the panel, while in the NSM technique the CFRP laminates are fixed into precut slits on the panel concrete joints. The NSM technique provided a higher increase on the panel load carrying capacity, as well as, a larger deflection at the failure of the panel.

The performance of EBR and NSM techniques for the strengthening of RC beams failing in shear is also analyzed. The NMS technique was much more effective in terms of increasing the beam load carrying capacity, as well as, the beam deformability at its failure. The NSM technique was easier and faster to apply than the EBR technique.
\end{abstract}

KEYWORDS: Carbon Fiber Reinforced Polymers, Strengthening, Concrete

\footnotetext{
* Corresponding author: Department of Civil Engineering, School of Engineering, University of Minho, Campus de Azurém, 4800-058 Guimarães, Portugal
} 


\section{INTRODUCTION}

The use of fiber reinforced polymer (FRP) materials for structural repair and strengthening has continuously increased during previous years, due to several advantages associated with these composites as compared to conventional materials like steel. These benefits include low weight, easy installation, high durability and tensile strength, electromagnetic neutrality and practically unlimited availability in size, geometry and dimension [1, 2].

FRP laminates and sheets are generally applied on the faces of the elements to be strengthened, using externally bonded reinforcing (EBR) technique. The research carried out up to now has revealed that this technique cannot mobilize the full tensile strength of FRP materials, due to premature debonding [3, 4]. Since FRP systems are directly exposed to weathering conditions, negative influences of freeze/thaw cycles [5] and the effect of high and low temperatures [6] should be taken into account in the reinforcing performance of these materials. In addition, EBR systems are susceptible to fire and acts of vandalism.

In an attempt at overcoming these drawbacks, a recent strengthening technique designated by near surface mounted (NSM) has been proposed, where FRP rods are fixed into pre-cut grooves on the concrete cover of the elements to be strengthened [7]. The CFRP was bonded to concrete by epoxy adhesive. This technique has been used in some practical applications $[8,9,10]$ and several benefits have been pointed out.

Blaschko and Zilch [11] proposed a similar strengthening technique based on introducing laminate strips of CFRP into pre-cut slits on the concrete cover. Despite the few number of tests carried out, their results revealed this to be a promising technique.

In recent years, carbon and glass FRP sheets have been applied using the retrofitting technique to increase concrete confinement $[12,13]$ and bending resistance [14] of reinforced concrete (RC) columns. This increase is dependent on the thickness (number of layers) and on the material properties of the FRP system [13,15], as well as on column crosssectional geometry [16]. Blaschko and Zilch [11] showed that the bending resistance of concrete elements can be significantly increased using laminate strips bonded to concrete into slits. The effectiveness of this strengthening technique, however, has not yet been appraised in concrete columns failing by bending and simultaneously submitted a 
kind of seismic loading configuration (lateral cyclic loading and static axial compression load). One of the goals of the present work is to assess the benefits of the NSM strengthening technique on this type of structural elements.

EBR techniques using CFRP materials have also been used to increase the shear resistance of RC beams [17, 18, 19]. Premature failures of these CFRP systems, however, inhibited the attainment of the desired strengthening efficacy level. In an attempt at obtaining a more effective shear strengthening technique for concrete beams, De Lorenzis et al. [20] used CFRP rods introduced into grooves made onto the vertical faces of concrete beams. This strengthening technique provided a significant increase on the shear resistance of the strengthened beams. Following similar strengthening technique procedures, but using laminate strips of CFRP bonded to concrete into thin slits, the effectiveness of this technique for shear strengthening is also assessed in the present work.

Sheets of FRP have also been used to increase the load carrying capacity of masonry walls but, when compared to the tensile strength of the used FRP, the mobilized stress level was often too low due either to premature debonding of these materials, or to local failures [21, 22]. If debonding is avoided, Triantafillou [23] showed the use of CFRP laminates is very effective in increasing the out-of-plane flexural resistance of masonry structures. With the aim of assuring higher resistance to debond, FRP rods, installed according to the NSM strengthening technique, have been recently used to strengthen masonry walls. This technique provided significant increase on the load carrying capacity and on the pseudoductility of the tested walls $[10,24]$. In the present work the effectiveness of the NSM and the EBR strengthening techniques was compared in terms of increasing the out-of-plane flexural resistance of masonry panels. However, instead of FRP rods, the strengthening system is now composed by CFRP laminate strips that, in the NSM technique were bonded into pre-cut slits on the concrete joints of the masonry panels, and in the EBR technique were externally glued in these joints.

\section{EXPERIMENTAL PROGRAM AND STRENGTHENING TECHNIQUE}

Table 1 summarizes the experimental program and its main objectives. It includes two groups of tests: a group of series of tests with RC columns, RC beams and masonry panels all failing in bending; and a group of RC beams failing in shear. These two groups have the main purpose of assessing the effectiveness of the NSM technique on elements failing 
in bending and on elements failing in shear, respectively. The percentage of the steel reinforcement ratio, $\rho_{s \ell}$ (ratio between the cross sectional area of longitudinal steel bars and the cross sectional area of the concrete element), has a recognized influence on the effectiveness of FRP strengthening techniques. To assess this influence on the NSM technique applied to RC elements failing in bending, tests with columns and beams of distinct $\rho_{s \ell}$ were carried out. The effectiveness of EBS and NSM techniques were compared in the series of masonry panels failing in bending and in the series of RC beams failing in shear.

The strengthening technique is made up of the following steps (see Figure 1):

- Using a diamond cutter, slits of 4 to $5 \mathrm{~mm}$ width and 12 to $15 \mathrm{~mm}$ depth are cut on the concrete surface of the elements to be strengthened;

- Slits are cleaned by compressed air;

- Laminate strips of CFRP are cleaned by acetone;

- Epoxy adhesive is produced according to supplier recommendations;

- Slits are filled with the epoxy adhesive;

- The epoxy adhesive is applied on the faces of the laminate strips of CFRP;

- Laminate strips of CFRP are introduced into the slits and the epoxy adhesive in excess is removed

The curing/hardening process of the epoxy adhesive lasted for, at least, five days prior to testing the strengthened elements.

\section{MATERIAL PROPERTIES}

\subsection{Concrete and steel bars}

Table 2 includes the main properties of the concrete and steel bars used in the experimental program. The concrete compression strength, $f_{c m}$, was obtained from uniaxial compression tests with cylinder specimens of $150 \mathrm{~mm}$ diameter and $300 \mathrm{~mm}$ height. The concrete tensile flexural strength, $f_{c t m, f}$, and the concrete fracture energy, $G_{f}$, were obtained from three point bending tests with notched beams, performed according to the recommendations of RILEM [25]. Each value is the average result of, at least, three tests. In the series of RC columns, low strength concrete and steel bars of 
moderate strength and smooth surface were used to obtain representative specimens of concrete columns of Portuguese buildings built before the 1980 s.

Steel bars were tested according to the standard EN 10 002-1 [26], and each result is the average of at least five tests.

\subsection{CFRP and epoxy adhesive}

According to the supplier, the MBrace Sheet C5-30 used as shear reinforcement in beams failing in shear, has the properties indicated in Table 3. Laminate strips of CFRP used in the NSM technique, with the designation of CFK 150/2000 10x1.4, were delivered in rolls and had cross sectional dimensions of $9.59 \pm 0.09$ mm width and $1.45 \pm 0.005 \mathrm{~mm}$ thickness (average values of fifteen measures). From three uniaxial tensile tests carried out according to ISO 527-5 standard [27], it was verified that the tensile behavior of the CFRP roll delivered for the concrete column group of tests was distinct from the tensile behavior registered in the rolls delivered for the beams and masonry panel groups of tests, see Table $3[28,29]$. This table also includes the Young's modulus and the tensile strength range of the epoxy adhesive used in the NSM technique, obtained from five uniaxial tensile tests carried out according to ISO 527-3 standard [30].

\subsection{Epoxy mortar}

To anchor the laminate strips of CFRP to the column foundation in the RC column test series, an epoxy mortar was used (see Figure 2). This epoxy mortar was composed of one part epoxy and three parts of previously washed and dried fine sand (parts measured in weight). Following the European standard EN 196-1 [31], an average compressive strength of $51.7 \mathrm{~N} / \mathrm{mm}^{2}$ and an average flexural tensile strength of $35.4 \mathrm{~N} / \mathrm{mm}^{2}$ was obtained at 28 days [32].

\subsection{Clay bricks}

The clay units used in the masonry panels had a length of $215 \mathrm{~mm}$, a width of $100 \mathrm{~mm}$, a height of $65 \mathrm{~mm}$ and two holes with a cross section of $25 \times 25 \mathrm{~mm}^{2}$. Due to the anisotropy associated with the extrusion process and firing, the compressive strength of the brick units was evaluated in the two orthogonal directions of length and unit height [33]. Data obtained from eight tests showed an average compression strength of $71.8 \mathrm{~N} / \mathrm{mm}^{2}$ in the length and $31.8 \mathrm{~N} / \mathrm{mm}^{2}$ in the height of the unit. The (direct) tensile strength of masonry units were obtained carrying out direct tension tests with 
notched specimens [34]. In the unit length direction, a tensile strength of $3.5 \mathrm{~N} / \mathrm{mm}^{2}$ was obtained, while a tensile strength of $1.76 \mathrm{~N} / \mathrm{mm}^{2}$ was recorded in the unit height direction. These values represent the average of at least ten specimens.

\section{CONCRETE COLUMNS FAILING IN BENDING}

\subsection{Series of tests}

Columns of reinforced concrete framed structures are the most vulnerable elements since their failure leads to the collapse of the structure. To assess the effectiveness of the NSM strengthening technique for concrete columns submitted to static axial compression load and cyclic horizontal increasing load, the three series of reinforced concrete columns, indicated in Table 4, were tested. Series NON consisted of non-strengthened columns, series PRE was composed of concrete columns strengthened with CFRP laminate strips before testing, and series POS consisted of previously tested columns of series NON which were post-strengthened with CFRP. The designation Pnm_s was attributed to tests of series $s$ (NON, PRE or POS), where $n$ represents the diameter of the longitudinal steel bars, in mm, (10 or 12), and $m$ can be $a$ or $b$, since there are two specimens for each series of distinct longitudinal steel reinforcement ratio.

\subsection{Test set-up and procedure}

The test set-up is illustrated in Figure 3, where it can be seen that each specimen is composed of a column monolithically connected to a footing fixed to a foundation block by four steel bars. A constant vertical load of approximately $150 \mathrm{kN}$ was applied to the column, inducing an axial compression stress of $3.75 \mathrm{~N} / \mathrm{mm}^{2}$. Linear variable displacement transducers (LVDTs) were used to record the horizontal displacements of the column as well as any vertical movement of the footing, see Figure 4. The position of the strain-gauges (SG) glued on the CFRP is also indicated in this figure. The tests were carried out with closed loop servo-controlled equipment. A history of displacements was imposed for LVDT1, located at the same height as the horizontal actuator, see Figures 3 and 4 . The history of horizontal displacements included eight load cycles between $\pm 2.5 \mathrm{~mm}$ and $\pm 20.0 \mathrm{~mm}$, in increments of $\pm 2.5 \mathrm{~mm}$, with a displacement rate of $150 \mu \mathrm{m} / \mathrm{s}$ [32]. 


\subsection{Specific strengthening procedures}

Figure 2 illustrates the strengthening technique adopted for the concrete columns. To anchor the CFRP laminate strips to the footing and to maintain their vertical position, the concrete cover of a region having a height of 100 to $150 \mathrm{~mm}$ from the bottom of the column (denoted here by "non-linear hinge region") was removed. Afterwards, slits were cut along the faces subjected to tensile stress. In the alignment of the slits, perforations of about $100 \mathrm{~mm}$ depth were made in the footing to anchor the CFRP laminate strips. The slits and the holes were cleaned using steel brushes and compressed air. After filling the slits with the epoxy adhesive, laminate strips of CFRP were inserted into the slits, and the "non-linear hinge region" and the holes in the footing were filled with epoxy mortar. A more detailed description of the strengthening technique is provided elsewhere [32].

\subsection{Results}

Representative results are presented in this section. Detailed results and analysis can be found elsewhere [32].

\subsubsection{Load carrying capacity}

The maximum compressive and tensile forces obtained in the tests are given in Tables 5 and 6 . The differences recorded in the maximum forces of the columns from the same series were due to the compression strength variability of the concrete of these columns (two batches were required to build a specimen), as well as differences in the positioning of the steel bars and their properties. Taking into account the results obtained from the non-strengthened columns (series NON), a significant increase in the maximum load of the columns of series PRE (strengthened before testing) and POS (strengthened after NON series had been tested) was observed. The comparison between series NON and PRE should be made with caution, because the concrete compression strength of the columns of these two series were not the same. As the CFRP reinforcement ratio was the same for all the column specimens tested, the increase of the ultimate load was larger in columns of a lower steel reinforcement ratio. The increase of the load carrying capacity in PRE and POS series was similar.

\subsubsection{Force-deflection relationship}

Figure 5 depicts a typical relationship between the horizontal force and the deflection at LVDT1 (see Figure 3). Since this strengthening technique does not provide significant concrete confinement, the increase on the dissipated energy 
was marginal [35]. The increment on the load carrying capacity, however, was significant as can be seen in Figure 6, where a typical envelope of the maximum values of the relationship between the maximum force registered in the load cycles and its corresponding deflection in the LVDT1 is represented.

\subsubsection{Force-strain relationship}

In the majority of the strengthened columns some laminate strips of CFRP reached tensile strain values close to the ultimate rupture strain of the CFRP (⒈0\%). Some CFRP laminate strips even failed at the main fracture surface of the concrete column. As an example, Figure 7 illustrates the relationship between the horizontal force applied to the column and the strain in the strain-gauge $S G 6$, for the column P10a_POS. In strain-gauges located at the concrete failure region, similar relationships to that depicted in Figure 7 were obtained in the remaining columns.

\section{CONCRETE BEAMS FAILING IN BENDING}

\subsection{Series of beams}

Figure 8 represents the geometry of the beams, the reinforcement arrangement and the number and position of the laminate strips of CFRP. The load configuration and the support conditions are also schematized. The cross sectional area of the CFRP, $A_{f}$, applied in the beam of each series, was designed to achieve twice the ultimate load of the corresponding reference beam. Shear reinforcement was selected to assure bending failure prior to shear failure for all beams. The cross sectional area of the tensile longitudinal steel bars is also indicated in Figure $8, A_{s}$. The longitudinal steel reinforcement was composed of bars of $6 \mathrm{~mm}$ and $8 \mathrm{~mm}$ diameters, while stirrups were made of bars of $6 \mathrm{~mm}$ diameter (in shear spans) and $3 \mathrm{~mm}$ diameter (in pure bending span). The beams were tested at the age of about 90 days.

\subsection{Test configuration and measuring devices}

To evaluate the strain evolution of the CFRP laminate strips, strain gauges were glued on one of their lateral faces, according to the scheme shown in Figure 9. This figure also represents the position of the LVDTs used for measuring the deflections of the beams. 


\subsection{Results}

Figure 10 represents the typical failure mode of the strengthened beams. The detached concrete layer at bottom of the beam has not uniform thickness and attained $60 \mathrm{~mm}$ in some parts. This reveals that, not only the concrete cover was detached, but also parts of concrete above the longitudinal reinforcement. More details can be found elsewhere [36].

\subsubsection{Force-deflection relationship}

The force-deflection relationships for the series of beams tested are depicted in Figure 11, and the main results are presented in Table 7. It is observed that the purpose of doubling the ultimate load $\left(F_{\max }\right)$ of the corresponding reference beam was practically achieved. The increase on the load at the onset of yielding the steel reinforcement ( $F_{s y}-$ yielding load) was also significant, varying from $32 \%$ to $47 \%$. The displacement corresponding to $F_{s y}$ increased, as well as the cracking load, $F_{c r}$, and the serviceability load, $F_{\text {serv }}$, (the load for a deflection of $L / 400=3.75 \mathrm{~mm}$, where $L$ is the beam span). A maximum increase of $45 \%$ on $F_{\text {serv }}$ was recorded. The sliding of the laminate strips of CFRP started to be visible before the collapse of the beam, at a load level after which the load increase was marginal.

\subsubsection{Force-strain relationship}

The relationships between the applied load and the strains recorded in the strain gauges glued onto the laminate strips of CFRP (see Figure 9) are depicted in Figure 12. The maximum strains obtained from the strengthened beams, and presented in Table $7\left(\varepsilon_{f, \max }\right)$, ranged from $62 \%$ to $91 \%$ of the CFRP ultimate rupture strain $\left(\varepsilon_{f u} \cong 1.7 \%\right.$ ), showing this strengthening technique has high level of effectiveness.

\section{CONCRETE BEAMS FAILING IN SHEAR}

\subsection{Series of tests}

A series of four point bending tests was carried out to assess the effectiveness of EBR and NSM strengthening techniques to increase the shear resistance of RC beams. The tested series of beams (see Figure 13) contain a reference beam without any shear reinforcement (VB10); a beam with steel stirrups of $6 \mathrm{~mm}$ diameter spaced at $150 \mathrm{~mm}$ in the shear spans (VBE-15); a beam with strips of CFRP MBrace C5-30 sheet (properties in Table 3) of two layers of $25 \mathrm{~mm}$ width and spaced at $80 \mathrm{~mm}$ in the shear spans (VBM-8); a beam with vertical laminate strips of CFRP bonded into pre- 
cut slits on the concrete cover of the vertical faces of the beam (see Figure 1c) and spaced at $100 \mathrm{~mm}(\mathrm{VBCV}-10)$; and a beam with inclined (45 degrees) laminate strips of CFRP fixed onto the beam like the previous one (VBCI-15). The strips of the CFRP sheet in VBM-8 beam had a "U" shape (embracing the bottom and vertical faces of the beam). The amount of shear reinforcement applied in the beams was designed to provide similar shear resistance [1] and to assure that they would fail in shear. The beams were tested at the age of 105 days.

\subsection{Results}

Figure 14 represents the relationship between the load and the displacement at mid span of the tested beams. The main results are presented in Table $8 . F_{\max , V B 10}$ and $F_{\max , V B E-15}$ represent the maximum load registered on the beam without shear reinforcement (VB10) and on the beam reinforced with steel stirrups (VBE-15), respectively. When compared to the reference beam (VB10), the beams strengthened with CFRP materials attained an increase in the maximum load, $F_{\max }$, ranging from $50 \%$ to $77 \%$. Taking $F_{\max , V B E-15}$ as a basis of comparison, it was verified that the maximum load of VBM-8, VBCV-10 and VBCI-15 beams was $92 \%, 109 \%$ and $100 \%$ of the $F_{\max , V B E-15}$, respectively. The highest and the lowest increase of $F_{\max }$ occurred in the beam strengthened with vertical laminate strips of CFRP (VBCV-10) and in the beam strengthened with strips of CFRP sheet (VBM-8), respectively. The lowest effectiveness of the EBR technique (in the VBM-8 beam) can be justified by the failure modes of the strengthened beams, see Figure 15 . In VBM- 8 beam a very fragile rupture occurred after the formation of the failure shear crack. The strips of CFRP sheet crossing the failure shear crack were ruptured at beam edges. Delamination between these strips of CFRP and concrete was also observed. The failure mode of the beams VBCV-10 and VBCI-15 was not as fragile as the failure mode of VBM-8 beam. Beam VB10 failed by the occurrence of one shear crack at one of the beam shear spans. In VBE-15 beam two shear cracks occurred, one in each beam shear spans. During the deflection process of this beam, the crack width of one of these cracks increased continuously up to the moment when a stirrup crossing this crack has ruptured, fixing the moment of the failure of the beam. For deflections larger than the deflection corresponding to peak load $\left(\delta_{p}\right)$, the beams reinforced with laminate strips of CFRP sustained appreciable residual force, which was not the case of beam VBM-8 and beam VBE-15 after the rupture of the stirrup crossing the shear failure crack. In VBCV-10 beam the cracks in the shear spans were almost enclosed between the two first laminate strips, from point load to support (see Figure 15). Due to the high inclination of these cracks, some plastic flow has occurred on the longitudinal steel bars, responsible for the "plateau" on the force-deflection relationship after peak load (see Figure 14). 
When compared to the deflection at maximum load of the reference beam $\left(\delta_{p, \mathrm{VB} 10}\right)$, the deflection at maximum load of beams VBE-15, VBCV-10, VBCI-15 and VBM-8 was, respectively, 294\%, 232\%, 119\% and 118\% larger. Therefore,

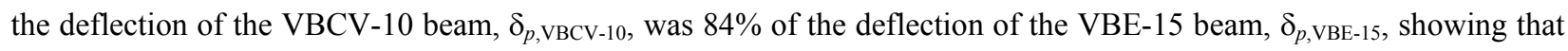
this strengthening technique was not only effective in terms of increasing the ultimate load, but also in assuring a high level of deformability at beam failure.

\section{MASONRY PANELS}

\subsection{Panel geometry, panel series, test set-up and strengthening techniques}

Masonry is a common construction practice in several countries, not only in walls and roofs but also in shells of sophisticated shapes. It has been used in the majority of their architectural heritage, with several masonry components needing strengthening intervention to increase their load carrying capacity to out-of-plane loadings. To compare the effectiveness of EBR and NSM strengthening techniques on achieving this goal for this type of construction, masonry panels strengthened by these two types of techniques were tested.

A panel specimen was made of ceramic units bonded by concrete joints and covered by a concrete compression layer (see Figure 1d). The laminate strips were installed in the longitudinal concrete joints of the panel using two strengthening techniques: externally bonded and bonded into slits made on the concrete joints. The geometry of the panel is represented in Figure 1d, and the three-line load out-of-plane bending test set-up is shown in Figure 16. Three series of masonry panels were tested, each one consisting of three specimens. One series, designated by reference series (panels P1, P2 and P3), had no reinforcement, while the other two series were strengthened with laminate strips of CFRP: one where the laminates were externally glued (panels P4, P5 and P6), and the other where the laminates were installed according to the NSM technique schematically described in Figure 1d (panels P7, P8 and P9). The laminate strips of CFRP were fixed to concrete using the epoxy adhesive described in section 3.2.

\subsection{Results}

Figure 17 represents the points of the maximum load and its corresponding deflection for the tested masonry panels. The obtained results are included in Table 9. In comparison with reference series, the CFRP externally and internally bonded to concrete joints had an increase in the maximum load of $92.2 \%$ and $103.6 \%$, respectively. In terms of deflection at maximum load, the series with CFRP externally and internally bonded to concrete joints attained average values of 
$37.5 \%$ and $173.7 \%$ larger than the average value of the reference series. The NSM technique was not only more effective in terms of increasing the load carrying capacity and the deformability at panel failure, but also in assuring higher uniformity in the behavior of the panel.

\section{SUMMARY AND CONCLUSIONS}

To appraise the effectiveness of a Near Surface Mounted (NSM) strengthening technique for elements failing in bending and elements failing in shear, series of tests with concrete columns, concrete beams and masonry panels were carried out. The NSM technique was based on bonding laminate strips of Carbon Fiber Reinforced Polymer (CFRP) into slits made onto the concrete cover of the elements to be strengthened. Data obtained from the carried out tests point out the following main observations.

\section{Concrete columns failing in bending}

A CFRP cross sectional area, $A_{f}$, of $0.2 \%$ of the column cross sectional area, $A_{c}$, provided an average increase of $92 \%$ and $34 \%$ on the load carrying capacity of columns reinforced with $4 \phi 10$ and $4 \phi 12$ longitudinal steel bars (cross sectional area, $A_{s}$, of $314 \mathrm{~mm}^{2}$ and $452 \mathrm{~mm}^{2}$, respectively, corresponding to a reinforcement ratio, $\rho_{s}=A_{s} / A_{c}$, of $0.79 \%$ and $1.13 \%)$. The premature debonding, generally occurring in the externally bonded reinforcing (EBR) technique, was avoided and strain values close to the CFRP ultimate rupture strain were measured on this composite material. Some CFRP laminates have even failed at the failure crack of the concrete columns. These results indicate that the proposed strengthening technique is very promising for increasing the load carrying capacity of concrete columns failing in bending.

\section{Concrete beams failing in bending}

The NSM strengthening technique was applied for doubling the load carrying capacity of concrete beams failing in bending. This purpose was practically attained since an average increase of $91 \%$ on the maximum load was obtained. In addition, high deformability at the failure of the strengthened beams was assured. The NSM technique provided an average increase of: $51 \%$ on the load corresponding to concrete cracking; $32 \%$ on the load corresponding to the deflection of the serviceability limit state analysis and $28 \%$ on the rigidity at this load level, which are important benefits for design purposes; and $39 \%$ on the load at the onset of yielding the steel reinforcement. Maximum strain values 
ranging from $62 \%$ to $91 \%$ of the CFRP ultimate rupture strain were registered, revealing that this technique can mobilize stress levels close to the tensile strength of this composite material.

\section{Concrete beams failing in shear}

The performance of EBR and NSM techniques on increasing the shear resistance of concrete beams failing in shear was compared. The NSM technique was based on bonding laminate strips of CFRP onto slits pre-cut onto the concrete cover of the vertical beam faces, which proved to be the most effective. The maximum load and the corresponding deflection of the beam strengthened with this technique were $9 \%$ larger and $16 \%$ smaller than the comparable values registered in the beam reinforced with steel stirrups of the equivalent shear reinforcement ratio. Beyond these structural benefits, it was verified that this technique was easier and faster to apply than the one based on embracing the beam with strips of CFRP sheet, which is a technique currently used for shear strengthening of concrete beams.

\section{Masonry panels}

Out-of-plane bending tests with masonry panels reinforced with laminate strips of CFRP showed that the technique based on introducing the CFRP into slits pre-cut onto panel concrete longitudinal joints can assure larger deformations at the failure of the masonry panels and larger maximum loads than the technique based on the external bonding of the CFRP. The former technique has also assured larger uniformity in the behavior of the panels tested, which is an important aspect in terms of safety.

\section{ACKNOWLEDGEMENTS}

The authors of the present work wish to acknowledge the support provided by the S\& $\mathrm{P}^{\circledR}$, Bettor $\mathrm{MBT}^{\circledR}$ Portugal, Secil, Nordesfer, Ferseque, Casais, Solusel, VSL, Unibetão (Braga) and the colaboration of Cemacom. The first author wishes to acknowledge the grant SFRH/BSAB/291/2002-POCTI, provided by FCT and FSE.

\section{APPENDIX: REFERENCES}

1. ACI Committee 440. Guide for the design and construction of externally bonded FRP systems for strengthening concrete structures. ACI, Technical report, May 2002, 118 pp. 
2. CEB-FIB. Externally bonded FRP reinforcement for RC structures. International Federation for Structural Concrete Technical report, July, 2001, 130 pp.

3. Nguyen DM, Chan TK, Cheong HK. Brittle failure and bond development length of CFRP-Concrete beams. Journal of Composites for Construction, February 2001, 5(1), 12-17.

4. Mukhopadhyaya P, Swamy RN. Interface shear stress: a new design criterion for plate debonding. Journal of Composites for Construction, February 2001, 5(1), 35-43.

5. Toutanji H, Balaguru P. Durability characteristics of concrete columns wrapped with FRP tow sheets. Journal of Materials in Civil Engineering, ASCE, 1998, 10(1), 52-57.

6. Pantuso A, Neubauer U, Rostasy FS. Effects of thermal mismatch between FRP and concrete on bond. In Minutes of 4th ConcreteFibreCrete Meeting, Lille, France, 2000.

7. De Lorenzis L, Nanni A, La Tegola A. Strengthening of reinforced concrete structures with near surface mounted FRP rods. International Meeting on Composite Materials, PLAST, Milan, Italy, May 2000, 8 pp.

8. Alkhrdaji T, Nanni A, Chen G, Barker M. Upgrading the transportation infrastructure: solid RD decks strengthened with FRP. ACI Concrete International Journal, 1999, 21(10), 37-41.

9. Hogue T, Cornforth RC, Nanni A. Myriad convention center floor system reinforcement. Proceedings of the FRPRCS-4, C.W. Dolan, S. Rizkalla and A. Nanni Editors, ACI, 1999, 1145-1161.

10. Tumialan JG, Galati N, Nanni A, Tyler D. Flexural strengthening of masonry walls in a high school using FRP bars. Field Application of FRP Reinforcement: Case Studies, ACI International SP-215, Eds. S. Rizkalla and A. Nanni, 2003, 413-428.

11. Blaschko M, Zilch K. Rehabilitation of concrete structures with CFRP strips glued into slits. Proceedings of the Twelfth International Conference of Composite Materials, ICCM 12, Paris, France, 1999.

12. Priestley MJN, Seible F. Design of seismic retrofit measures for concrete and masonry structures. Construction and Building Materials, 1995, 9(6), 365-377.

13. Xiao Y, Wu H. Compressive behavior of concrete confined by carbon fiber composite jackets. Journal of Materials in Civil Engineering, 2000, 12(2), 139-146. 
14. Meier U. Bridge repair with high performance composites materials. Mater. Tech., Vol. 4, 1987, 125-128.

15. Untiveros C. Estudio Experimental del comportamiento del hormigón confinado sometido a compresión. PhD Thesis, UPC, Barcelona, Spain, 2000. (in Spanish)

16. Mirmiran A, Shahawy M, Samaan M, Echary HE, Mastrapa JC, Pico O. Effect of column parameters on FRP confined concrete. Journal of Composites for Construction, 1998, 2(4), 175-185.

17. Taerwe L, Khalil H, Matthys S. Behaviour of RC beams strengthened in shear by external CFRP sheets. Proceedings of the Third International Symposium Non-Metallic (FRP) Reinforcement for Concrete Structures, Vol. 1, Tokyo, October 1997, 483-490.

18. Chaallal O, Nollet MJ, Perraton D. Renforcement au cisaillement de poutres en béton armé par des lamelles composites collées à láide de résine époxy. Bulletin des Laboratoires des Ponts et Chaussees - 212, Novembre/Decembre $1997,87-93$.

19. Triantafillou T. Shear strengthening of reinforced concrete beams using epoxy-bonded FRP composites. ACI Structural Journal, March-April 1998, 107-115.

20. De Lorenzis L, Nanni A, La Tegola A. Flexural and shear strengthening of reinforced concrete structures with near surface mounted FRP rods. Proceedings of the Third International Conference on Advanced Composite Materials in Bridges and Structures, Ottawa, Canada, Editors: J. Humar and A.G. Razaqpur, August 2000, 521-528.

21. Modena C, Valuzzi MR. Repair and upgrading techniques of historic masonry buildings: researchers and applications. 7th Int. Conf. on Inspection, Appraisal, Repairs \& Maintenance of Buildings \& Structures, Nottingham, UK, 2001, 93-106.

22. Galati N. Out-of-plane behaviour of masonry walls strengthened with FRP materials. PhD Thesis, University of Lecce, Italy, 2003.

23. Triantafillou T. Strengthening of masonry structures using epoxy-bonded FRP laminates. Journal of Composites for Construction, 1998, 2(2), 96-104.

24. Tumialan JG, Galati N, Namboorimadathil SM, Nanni A. Strengthening of masonry with near surface mounted FRP bars. International Conference on Composites in Infrastructure (ICCI2002), San Francisco, USA, 2002. 
25. RILEM Draft Recommendation, 50-FMC Committee Fracture Mechanics of Concrete. Determination of the fracture energy of mortar and concrete by means of three-point bending tests on notched beams. Materials and Structures, 1985, 85(85), 285-290.

26. EN 10 002-1. Metallic materials. Tensile testing. Part 1: Method of test (at ambient temperature). 1990, 35 pp.

27. ISO 527-5. Plastics - Determination of tensile properties - Part 5: Test conditions for unidirectional fibre-reinforced plastic composites. International Organization for Standardization, Genève, Switzerland, 1997, 9 pp.

28. Sena-Cruz JM, Barros JAO, Faria RMCM. Assessing the embedded length of epoxy-bonded carbon laminates by pull-out bending tests. International Conference Composites in Construction, Porto, Portugal, October 2001, $217-222$.

29. Sena-Cruz JM, Barros JAO. Bond behavior of carbon laminate strips into concrete by pullout-bending tests. Bond in Concrete - from the research to standards, International Symposium, November 2002, Budapest, Hungry, 614-621.

30. ISO 527-3. Plastics - Determination of tensile properties - Part 5: Test conditions for unidirectional fibre-reinforced plastic composites. International Organization for Standardization, Genève, Switzerland, 1997, 5 pp.

31. EN 196-1. Methods of testing cement. Part 1: Determination of strength. 1996, 26 pp.

32. Ferreira DRSM. Pilares de Betão Armado Reforçados com Laminados de Fibras de Carbono (Reinforced concrete columns strengthened with CFRP laminates). MSc Thesis, Civil Eng. Dep., University of Minho, Portugal, 2000. (in Portuguese)

33. Lourenço PJB, Barros JAO, Oliveira JT. Shear testing of stack bonded masonry. Accepted to be published in the Journal of Construction and Building Materials.

34. Almeida JC, Lourenço PJB, Barros JAO. Characterization of brick and brick -mortar interface under uniaxial tension. In: Santos F.A. et al., editors. Proceedings of 7th Int. Seminar on Structural Masonry, Brazil: CEFET-MG, 2002, 67-76.

35. Barros JAO, Sena-Cruz JM, Ferreira DRSM, Lourenço PJB. Análise experimental de pilares de betão armado reforçados com laminados de carbono sob acções cíclicas (Experimental analysis of concrete columns submitted to cyclic loading and strengthened with CFRP laminates). $5^{\circ}$ Encontro Nacional de Sismologia e Engenharia Sísmica, Laboratório Regional de Engenharia Civil, Ponta Delgada, Açores, 2001, 491-503. (in Portuguese) 
36. Fortes AS, Barros JAO, Padaratz IJ. Vigas de betão armado reforçadas com laminados de CFRP inseridos no betão de recobrimento ( $\mathrm{RC}$ beams strengthened with CFRP laminate strips embedded into slips). Technical report 02-DEC/E13, 2002, 32 pp. (in Portuguese) 
Table 1. Experimental program

\begin{tabular}{|c|c|c|c|c|}
\hline Group of tests & \multicolumn{3}{|c|}{ Elements failing in bending } & Elements failing in shear \\
\hline Type of element & $\begin{array}{c}\text { RC columns } \\
\text { (Fig. 1a and Figs. 2, 3) }\end{array}$ & $\begin{array}{c}\text { RC beams } \\
\text { (Fig. } 1 \mathrm{~b} \text { and Fig. } 8 \text { ) }\end{array}$ & $\begin{array}{l}\text { Masonry panels } \\
\text { (Fig. 1d and Fig. 16) }\end{array}$ & $\begin{array}{c}\text { RC beams } \\
\text { (Fig. 1c and Fig. 13) }\end{array}$ \\
\hline Type of test & Cyclic tests & \multicolumn{3}{|c|}{ Monotonic tests } \\
\hline Load configuration & $\begin{array}{l}\text { Constant axial compression } \\
\text { load and cyclic horizontal } \\
\text { increasing load }\end{array}$ & Four point bending tests & Three line bending tests & $\begin{array}{l}\text { Four point } \\
\text { bending tests }\end{array}$ \\
\hline Aim & Assess the influence of $\rho_{s l}{ }^{1}$ & \multicolumn{3}{|c|}{ Compare the performance of EBR and NSM techniques } \\
\hline $\begin{array}{l}\text { Variables of the } \\
\text { experimental program }\end{array}$ & Two distinct $\rho_{s l}$ & Four distinct $\rho_{s l}$ & $\begin{array}{c}\text { Laminate strips glued } \\
\text { externally and embedded } \\
\text { into slits }\end{array}$ & $\begin{array}{l}\text { Strips of wet lay-up } \\
\text { CFRP; CFRP laminates } \\
\text { embedded into slits }\end{array}$ \\
\hline
\end{tabular}

${ }^{1} \rho_{s l}=$ Ratio between the cross sectional area of tensile longitudinal steel bars $\left(A_{s}\right)$ and the concrete cross sectional area $\left(A_{c}\right)$

Table 2. Properties of the concrete and steel bars

\begin{tabular}{|c|c|c|c|c|c|c|c|}
\hline & & & Concrete & & & Steel & \\
\hline & & $\begin{array}{c}f_{c m} \\
{[\mathrm{MPa}]}\end{array}$ & $\begin{array}{l}f_{c t m, f l} \\
{[\mathrm{MPa}]}\end{array}$ & $\begin{array}{c}G_{f} \\
{[\mathrm{~N} / \mathrm{mm}]}\end{array}$ & $\begin{array}{c}\phi_{s} \\
{[\mathrm{~mm}]}\end{array}$ & $\begin{array}{c}f_{s y} \\
{[\mathrm{MPa}]}\end{array}$ & $\begin{array}{c}f_{s u} \\
{[\mathrm{MPa}]}\end{array}$ \\
\hline \multirow{6}{*}{ 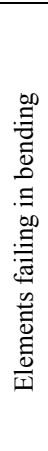 } & \multirow{3}{*}{$\mathrm{RC}$ columns } & \multirow{3}{*}{$16.7(28)^{1}$} & \multirow{3}{*}{$2.62(28)$} & \multirow{3}{*}{$0.08(28)$} & 6 & 352.4 & 532.8 \\
\hline & & & & & 10 & 323.3 & 456.5 \\
\hline & & & & & 12 & 364.8 & 518.8 \\
\hline & \multirow[b]{2}{*}{$\mathrm{RC}$ beams } & \multirow[b]{2}{*}{$46.1(90)$} & \multirow[b]{2}{*}{ - } & \multirow[b]{2}{*}{-} & 6 & & 750 \\
\hline & & & & & 8 & & 500 \\
\hline & Masonry panels & $45(28)$ & - & - & - & - & - \\
\hline \multirow{3}{*}{ 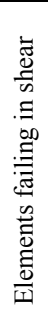 } & \multirow{3}{*}{$\mathrm{RC}$ beams } & \multirow{3}{*}{$\begin{array}{l}49.5(28) \\
56.2(105)\end{array}$} & \multirow{3}{*}{ - } & \multirow{3}{*}{ - } & $\begin{array}{c}\text { (stirrups) } \\
6\end{array}$ & 540 & 694 \\
\hline & & & & & $\begin{array}{c}\text { (longitudinal) } \\
6\end{array}$ & 618 & 691 \\
\hline & & & & & 10 & 464 & 581 \\
\hline
\end{tabular}

1 - The values in brackets represent the age, in days, when the tests were carried out. 
Table 3. Properties of the CFRP materials

\begin{tabular}{|c|c|c|c|c|c|c|}
\hline \multicolumn{3}{|c|}{ CFRP system } & \multicolumn{4}{|c|}{ Main properties } \\
\hline \multicolumn{2}{|l|}{ Type } & Material & $\begin{array}{c}\text { Tensile strength } \\
\text { (MPa) }\end{array}$ & $\begin{array}{c}\text { Young's modulus } \\
\text { (GPa) }\end{array}$ & $\begin{array}{c}\text { Ultimate strain } \\
(\%)\end{array}$ & $\begin{array}{c}\text { Thickness } \\
\text { (mm) }\end{array}$ \\
\hline \multirow{3}{*}{\multicolumn{2}{|c|}{ MBrace Sheet C5-30 ${ }^{1}$}} & Primer & 12 & 0.7 & 3.0 & - \\
\hline & & Epoxy & 54 & 3 & 2.5 & - \\
\hline & & Sheet & 3000 & 390 & 0.8 & 0.167 \\
\hline \multirow{3}{*}{$\begin{array}{c}\text { CFK } \\
150 / 200010 \times 1.4^{2}\end{array}$} & & Adhesive & $16-22$ & 5 & - & - \\
\hline & \multirow{2}{*}{ 荀 } & Columns & 1741 & 153 & 1.1 & 9.6 \\
\hline & & $\begin{array}{c}\text { Beams and masonry } \\
\text { panels }\end{array}$ & 2740 & 158 & 1.7 & 9.6 \\
\hline
\end{tabular}

${ }^{2}$ Evaluated from experimental tests

Table 4. Denominations for the RC column specimens

\begin{tabular}{c|c|c|c}
\hline \multirow{2}{*}{$\begin{array}{c}\text { Longitudinal steel } \\
\text { reinforcement }\end{array}$} & \multicolumn{3}{|c}{ Series } \\
\cline { 2 - 4 } & NON $^{1}$ & PRE $^{2}$ & POS $^{3}$ \\
\hline $4 \phi 10$ & P10a_NON & P10a_PRE & P10a_POS \\
\cline { 2 - 4 }$\left(A_{s l}=314 \mathrm{~mm}^{2}\right)$ & P10b_NON & P10b_PRE & P10b_POS \\
\hline $4 \phi 12$ & P12a_NON & P12a_PRE & P12a_POS \\
\cline { 2 - 4 }$\left(A_{s l}=452 \mathrm{~mm}^{2}\right)$ & P12b_NON & P12b_PRE & P12b_POS
\end{tabular}

${ }^{1}$ Non-strengthened; ${ }^{2}$ Strengthened before testing;

${ }^{3}$ Columns of NON series after have been tested and strengthened.

Table 5. Maximum forces obtained in the columns of series PRE

\begin{tabular}{c|c|c|c|c}
\hline \multirow{2}{*}{ Force } & \multicolumn{4}{|c}{ Series PRE } \\
\cline { 2 - 5 } & $\begin{array}{c}\text { P10a_PRE } \\
(111)\end{array}$ & $\begin{array}{c}\text { P10b_PRE } \\
(113)\end{array}$ & $\begin{array}{c}\text { P12a_PRE } \\
(110)\end{array}$ & $\begin{array}{c}\text { P12b_PRE } \\
(115)\end{array}$ \\
\hline Tensile $[\mathrm{kN}]$ & 37.14 & 40.63 & 44.13 & 39.81 \\
\hline Compressive $[\mathrm{kN}]$ & -38.54 & -37.96 & -43.66 & -36.64 \\
\hline
\end{tabular}

Note: Values inside brackets represent the age of the columns at testing, in days. 
Table 6. Maximum forces obtained in the columns of NON and POS series

\begin{tabular}{c|c|c|c|c|c}
\hline Force & Series & P10a_ & P10b_ & P12a_ & P12b_ \\
\hline \multirow{4}{*}{ Tensile } & NON [kN] & $16.67(86)$ & $21.78(85)$ & $26.35(85)$ & $29.31(85)$ \\
\cline { 2 - 6 } & POS [kN] & $37.96(146)$ & $41.38(130)$ & $34.11(150)$ & $45.54(154)$ \\
\cline { 2 - 6 } & Increase [\%] & 127.70 & 89.99 & 29.45 & 55.37 \\
\hline \multirow{4}{*}{ Compressive } & NON [kN] & $-19.76(86)$ & $-24.07(85)$ & $-30.52(85)$ & $-32.27(85)$ \\
\cline { 2 - 6 } & POS [kN] & $-34.11(146)$ & $-43.1(130)$ & $-37.03(150)$ & $-41.58(154)$ \\
\cline { 2 - 6 } & Increase [\%] & 72.62 & 79.06 & 21.33 & 28.85 \\
\hline
\end{tabular}

Note: Values inside brackets represent the age of the columns at testing, in days.

Table 7. Main results obtained in the series of beams failing in bending

\begin{tabular}{|c|c|c|c|c|c|c|c|c|c|c|}
\hline Series & Beam & $\begin{array}{c}F_{c r} \\
{[\mathrm{kN}]}\end{array}$ & $\frac{F_{c r}(V R)}{F_{c r}(V)}$ & $\begin{array}{l}F_{\text {serv }} \\
{[\mathrm{kN}]}\end{array}$ & $\frac{F_{\text {serv }}(V R)}{F_{\text {serv }}(V)}$ & $\begin{array}{c}F_{s y} \\
{[\mathrm{kN}]}\end{array}$ & $\frac{F_{s y}(V R)}{F_{s y}(V)}$ & $\begin{array}{l}F_{\max } \\
{[\mathrm{kN}]}\end{array}$ & $\frac{F_{\max }(V R)}{F_{\max }(V)}$ & $\begin{array}{c}\mathcal{E}_{f, \max } \\
(\%)\end{array}$ \\
\hline \multirow{2}{*}{$\mathrm{S} 1$} & V1 & 8.5 & \multirow{2}{*}{1.26} & 18.6 & \multirow{2}{*}{1.22} & 24.5 & \multirow{2}{*}{1.32} & 28.2 & \multirow{2}{*}{1.78} & \\
\hline & V1R1 & 10.7 & & 22.7 & & 32.31 & & $50.3^{(2)}$ & & 1.55 \\
\hline \multirow{2}{*}{ S2 } & $\mathrm{V} 2$ & 8.1 & \multirow{2}{*}{1.52} & 21.7 & \multirow{2}{*}{1.45} & 37.5 & \multirow{2}{*}{1.39} & 41.0 & \multirow{2}{*}{1.91} & \\
\hline & V2R2 & 12.3 & & 31.4 & & 52.28 & & 78.5 & & 1.28 \\
\hline \multirow{2}{*}{ S3 } & V3 & 7.9 & \multirow{2}{*}{1.51} & 23.8 & \multirow{2}{*}{1.38} & 40.0 & \multirow{2}{*}{1.36} & 41.3 & \multirow{2}{*}{1.98} & \\
\hline & V3R2 & 11.9 & & 32.8 & & 54.52 & & 81.9 & & 1.28 \\
\hline \multirow{2}{*}{ S4 } & V4 & 8.1 & \multirow{2}{*}{1.74} & 32.3 & \multirow{2}{*}{1.25} & 46.9 & \multirow{2}{*}{1.47} & 48.5 & \multirow{2}{*}{1.96} & \\
\hline & V4R3 & 14.1 & & 40.4 & & 69.11 & & 94.9 & & 1.06 \\
\hline
\end{tabular}

(1) VR - Strengthened beam; V - Reference beam.

(2) The test was canceled at a load of $50.3 \mathrm{kN}$, when the deflection at mid span was greater than $25 \mathrm{~mm}$.

Table 8. Main results obtained in the series of beams failing in shear

\begin{tabular}{|c|c|c|c|c|c|c|c|}
\hline \multirow{2}{*}{ Beam } & \multirow[b]{2}{*}{ Strengthening system } & $F_{\max }$ & $F_{\text {max }}$ & $F_{\max }$ & \multirow{2}{*}{$\begin{array}{c}\delta_{p} \\
{[\mathrm{~mm}]}\end{array}$} & \multirow{2}{*}{$\frac{\delta_{p}}{\delta_{p, V B 10}}$} & \multirow{2}{*}{$\frac{\delta_{p}}{\delta_{p, V B E-15}}$} \\
\hline & & {$[\mathrm{kN}]$} & $\overline{F_{\max , V B 10}}$ & $\overline{F_{\max , V B E-15}}$ & & & \\
\hline VB10 & - & 74.02 & 1.00 & 0.61 & 1.92 & 1.00 & 0.25 \\
\hline VBE-15 & Steel stirrups & 120.64 & 1.63 & 1.00 & 7.57 & 3.94 & 1.00 \\
\hline VBM-8 & Strips of CFRP sheets & 111.14 & 1.50 & 0.92 & 4.18 & 2.18 & 0.55 \\
\hline VBCV-10 & Vertical CFRP laminates & 131.22 & 1.77 & 1.09 & 6.37 & 3.32 & 0.84 \\
\hline VBCI-15 & Inclined CFRP laminates & 120.44 & 1.63 & 1.00 & 4.21 & 2.19 & 0.56 \\
\hline
\end{tabular}


Table 9. Main results of series of masonry panels

\begin{tabular}{|c|c|c|c|c|c|}
\hline Series & $\begin{array}{c}\text { Panel } \\
\text { designation }\end{array}$ & $\begin{array}{l}F_{\max } \\
{[\mathrm{kN}]}\end{array}$ & $\begin{array}{l}\bar{F}_{\max } \\
{[\mathrm{kN}]}\end{array}$ & $\begin{array}{c}\delta_{p} \\
{[\mathrm{~mm}]}\end{array}$ & $\begin{array}{c}\bar{\delta}_{p} \\
{[\mathrm{~mm}]}\end{array}$ \\
\hline \multirow{3}{*}{ Reference } & P1 & 13.01 & \multirow{3}{*}{16.90} & 1.16 & \multirow{3}{*}{1.52} \\
\hline & $\mathrm{P} 2$ & 17.73 & & 1.34 & \\
\hline & P3 & 19.97 & & 2.05 & \\
\hline \multirow{3}{*}{$\begin{array}{l}\text { CFRP fixed } \\
\text { externally }\end{array}$} & $\mathrm{P} 4$ & 30.29 & \multirow{3}{*}{32.49} & 2.36 & \multirow{3}{*}{2.09} \\
\hline & P5 & 29.94 & & 1.69 & \\
\hline & P6 & 37.25 & & 2.21 & \\
\hline \multirow{3}{*}{$\begin{array}{l}\text { CFRP fixed } \\
\text { internally }\end{array}$} & P7 & 36.12 & \multirow{3}{*}{34.4} & 4.60 & \multirow{3}{*}{4.16} \\
\hline & P8 & 34.55 & & 3.96 & \\
\hline & P9 & 32.53 & & 3.93 & \\
\hline
\end{tabular}

$F_{\max }:$ maximum load; $\bar{F}_{\max }:$ average of the maximum load of the series.

$\delta_{p}:$ displacement at maximum load; $\bar{\delta}_{p}$ : average of the displacement at maximum load of the series. 


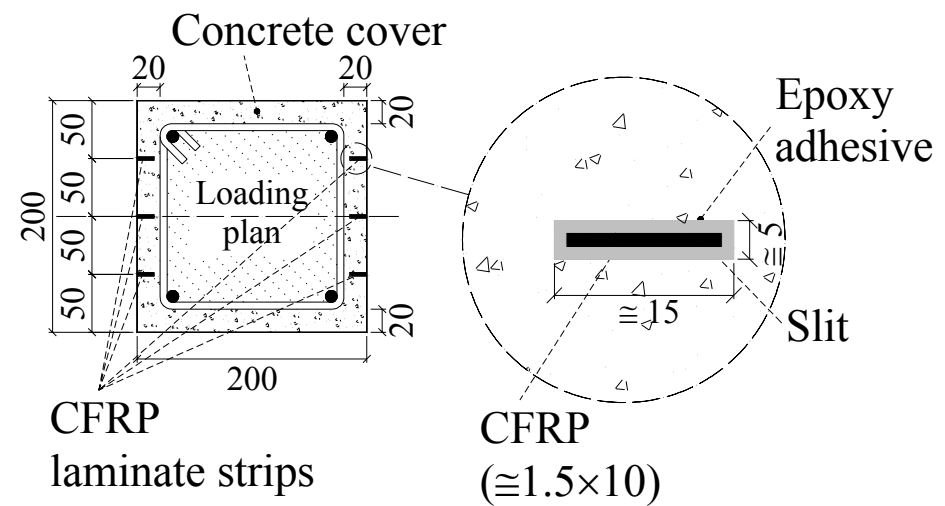

(a)

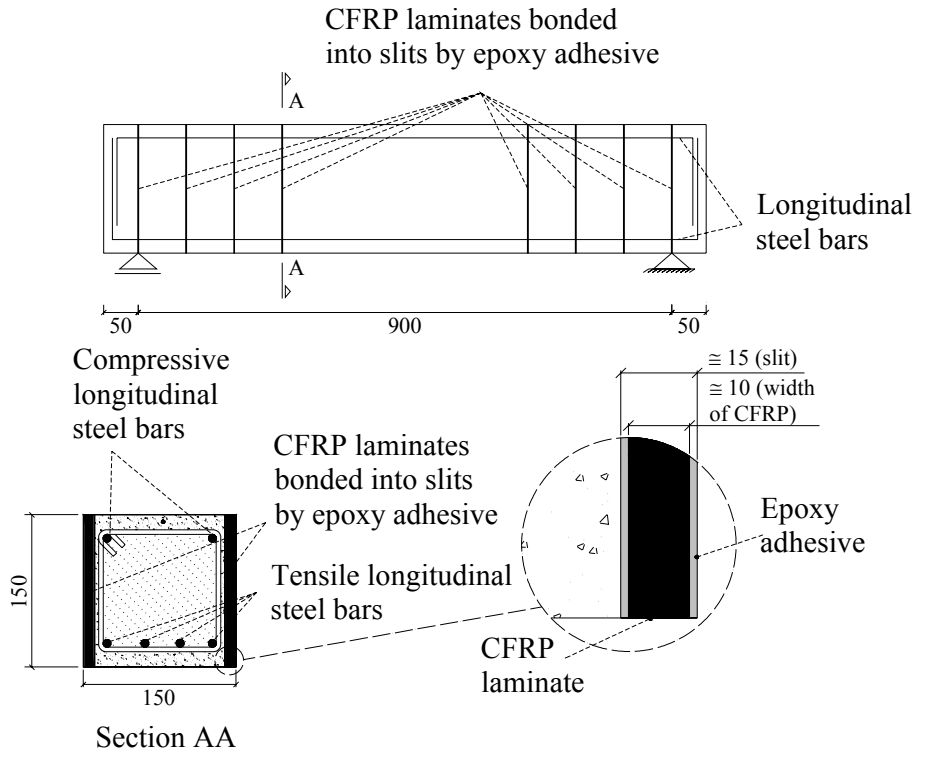

(c)

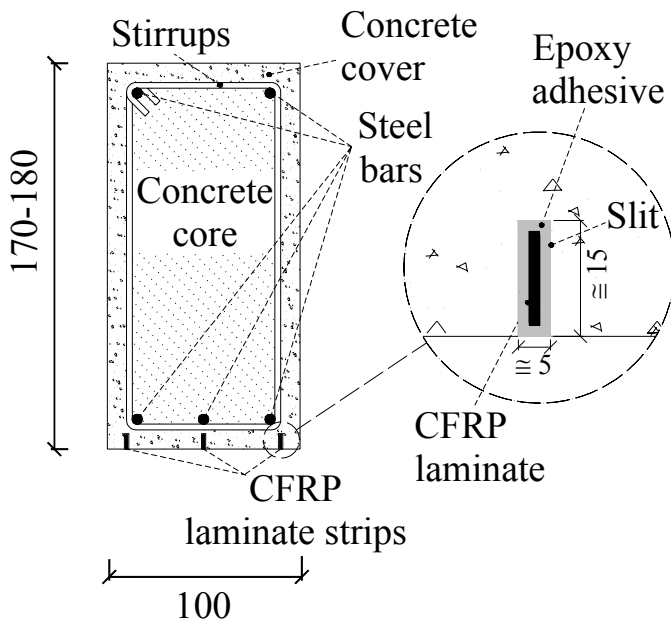

(b)

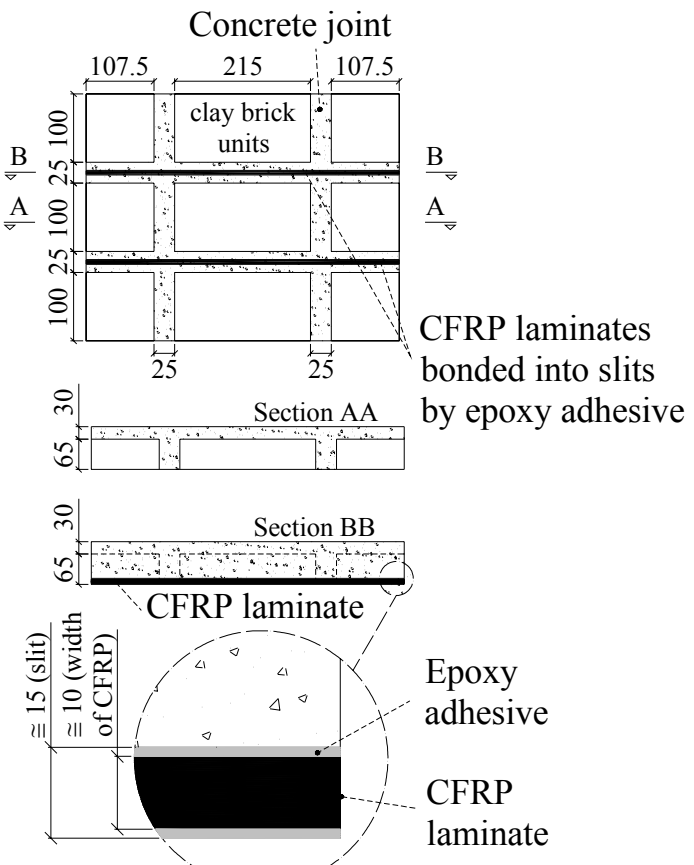

(d)

Figure 1. NSM CFRP strengthening technique for: (a) concrete columns failing in bending; (b) concrete beams failing in bending; (c) concrete beams failing in shear; (d) masonry failing in bending (dimensions in $\mathrm{mm}$ ) 


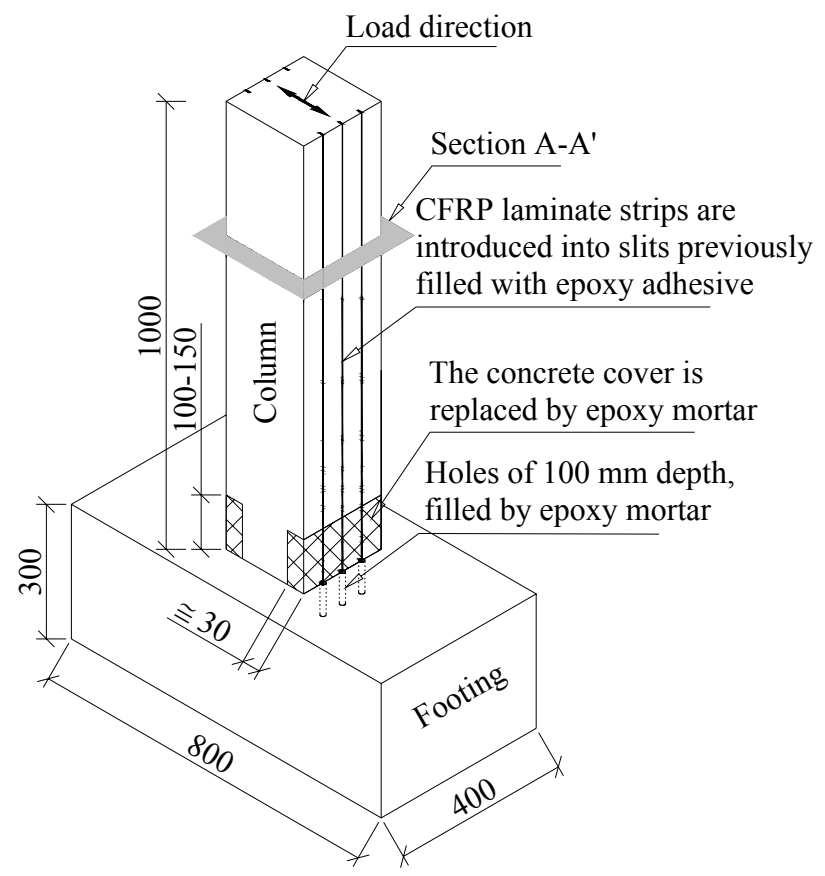

Figure 2. Strengthening technique in specimens of RC column (Section A-A' in Figure 1a; dimensions in mm)

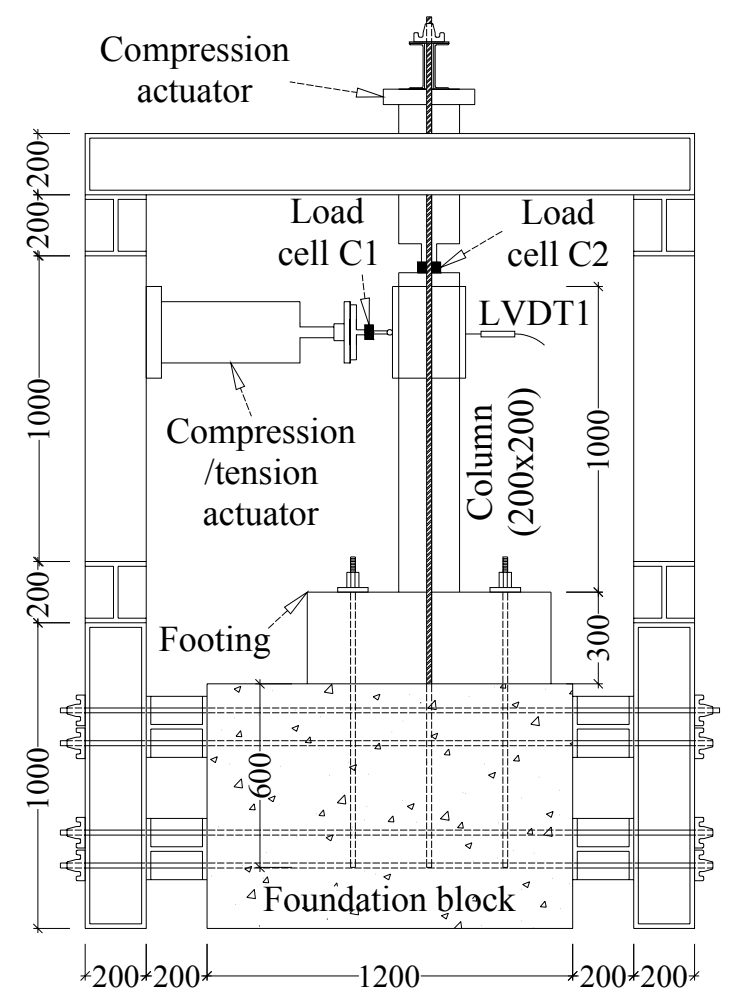

Figure 3. Test set-up (dimensions in $\mathrm{mm}$ ) 


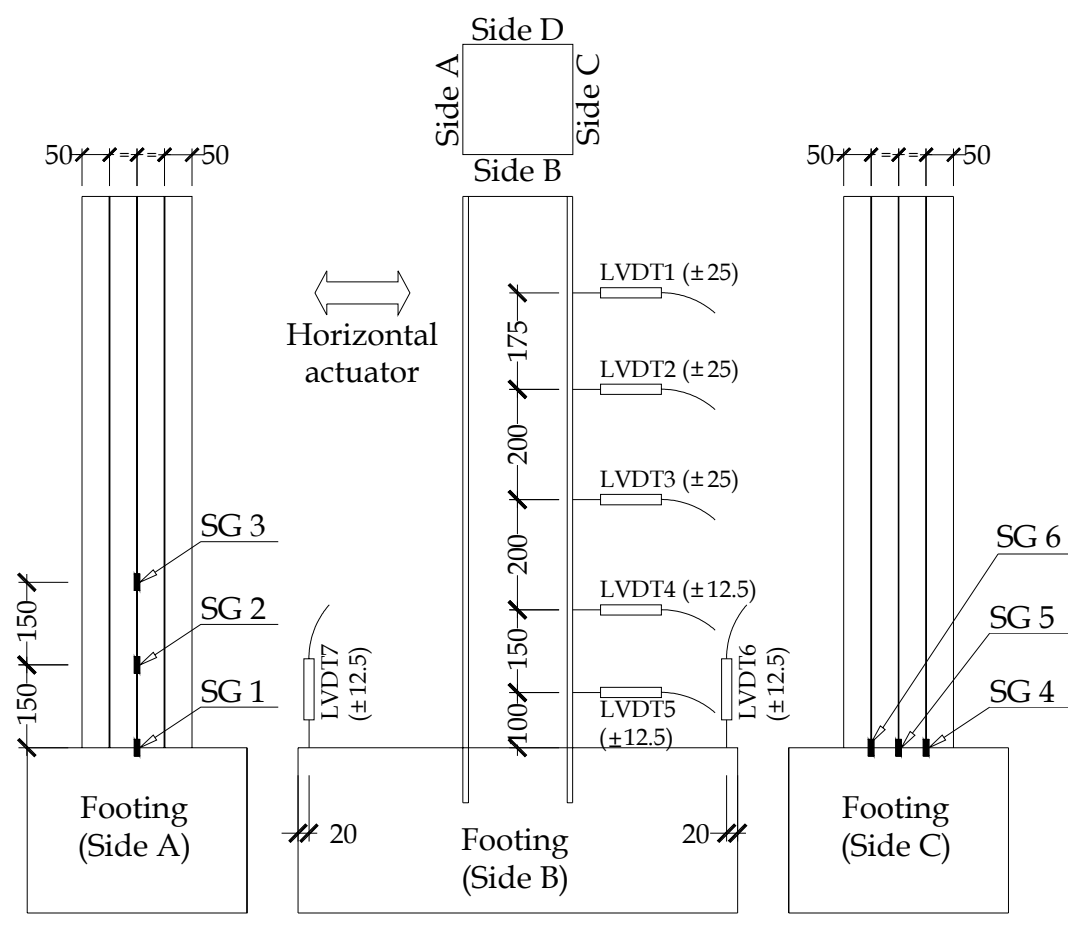

Figure 4. Location of the displacement transducers (LVDT) and strain gauges (SG) in test set-up (dimensions in $\mathrm{mm}$ )

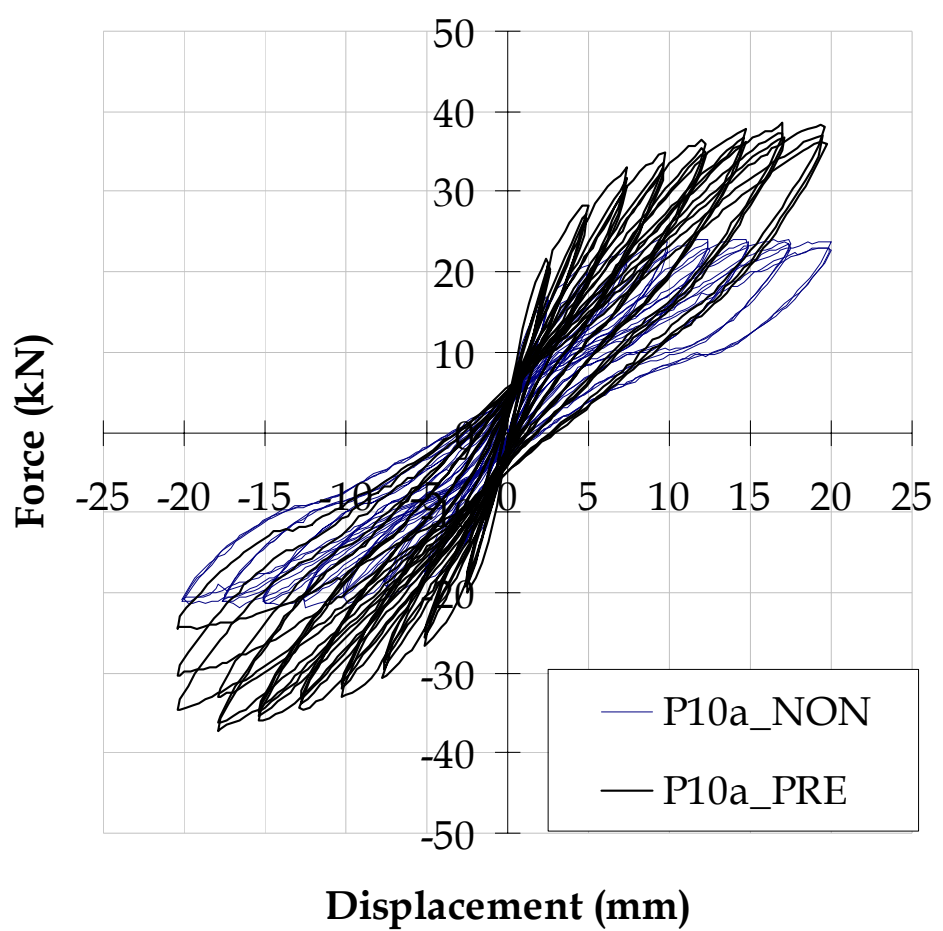

Figure 5. Cyclic force-deflection (at LVDT1) relationship for column P10a 


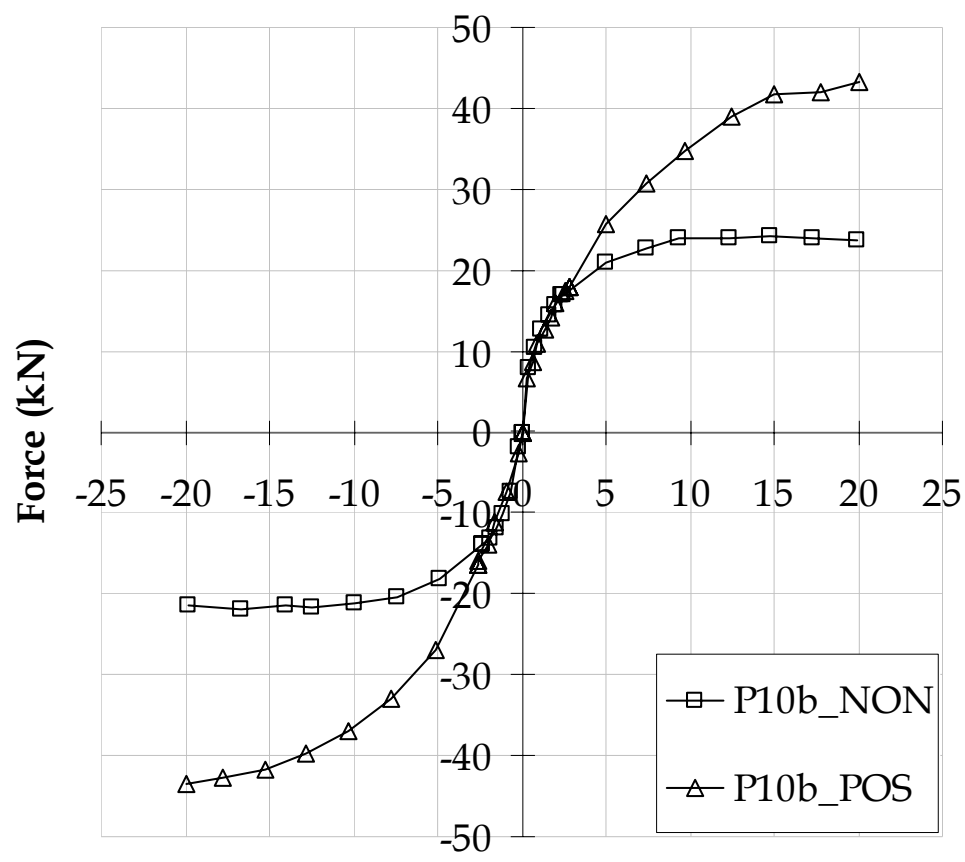

Displacement (mm)

Figure 6. Force-deflection (at LVDT1) envelop of all load cycles for column P10b

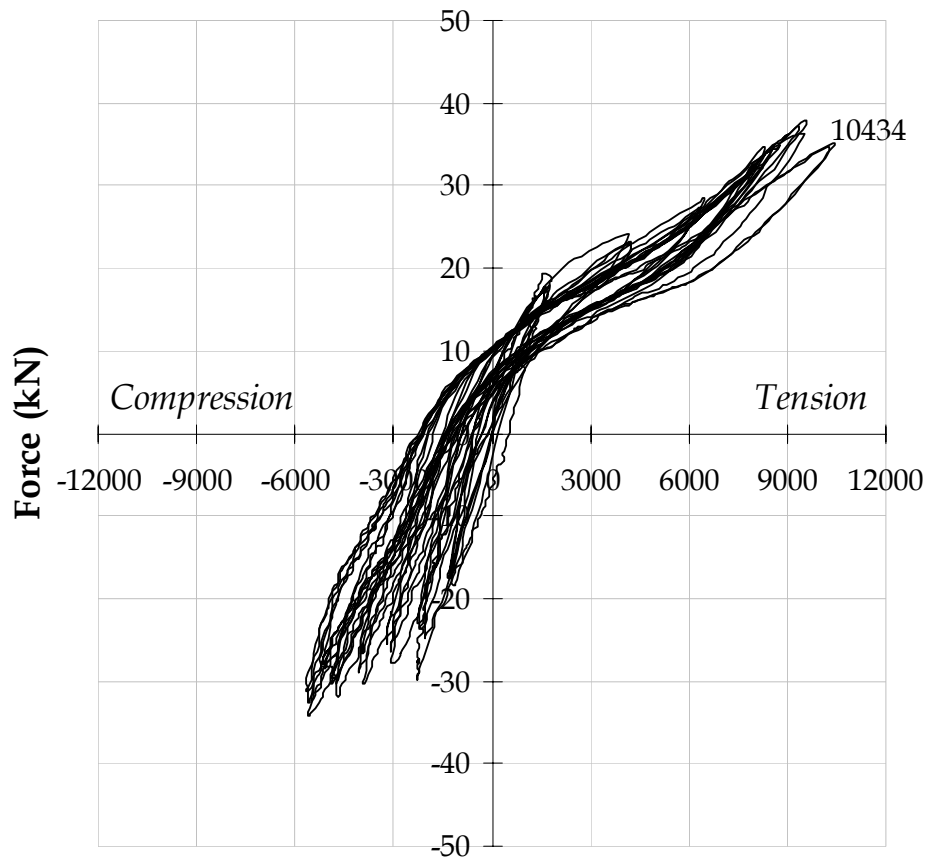

Strain $(\mu \mathrm{m} / \mathrm{m})$

Figure 7. Relationship between the force and the strain on the strain gauge SG6 (see Figure 4) for the column P10a_POS 


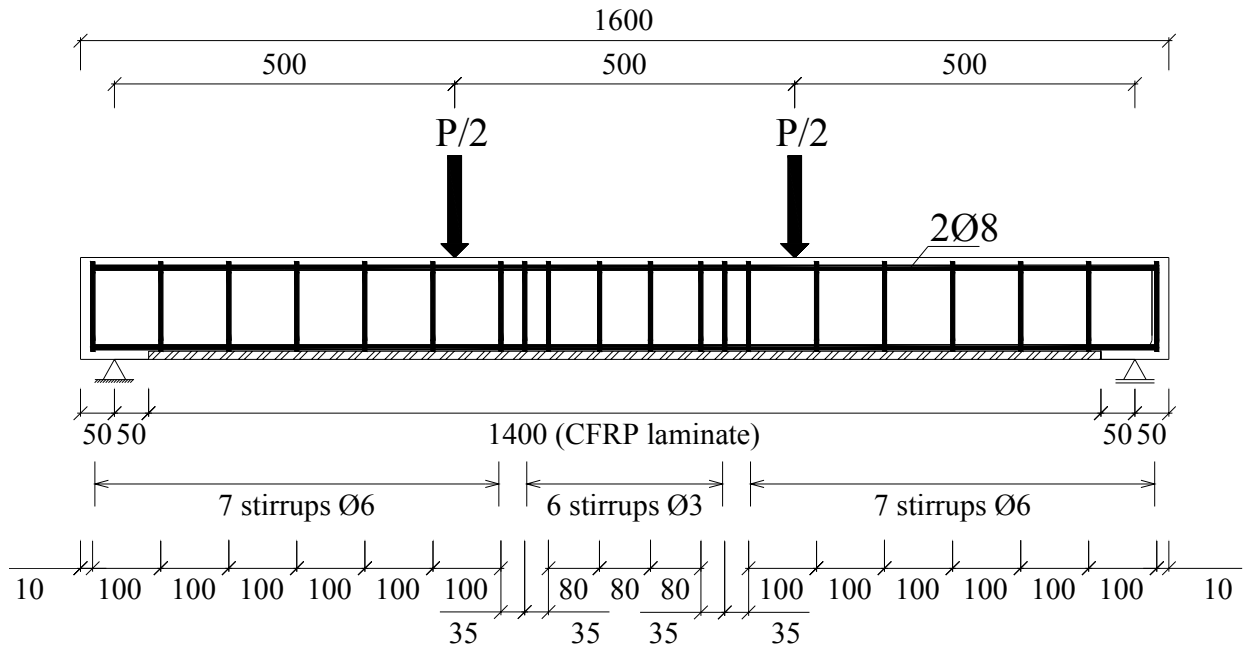

(a)

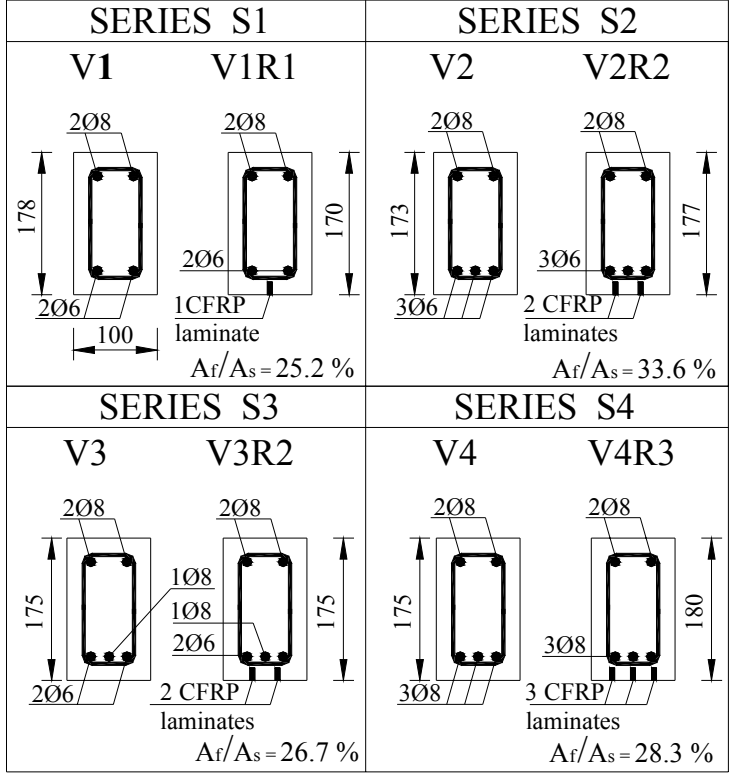

(b)
CFRP laminates
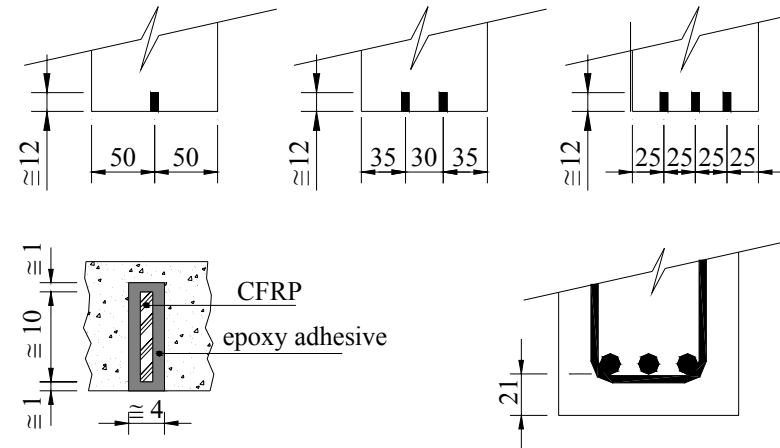

Figure 8. Series of beams failing in bending: (a) load configuration and arrangement of longitudinal reinforcement, (b) cross section of series of beams, (c) details of the positioning of the CFRP laminates (dimensions in mm) 


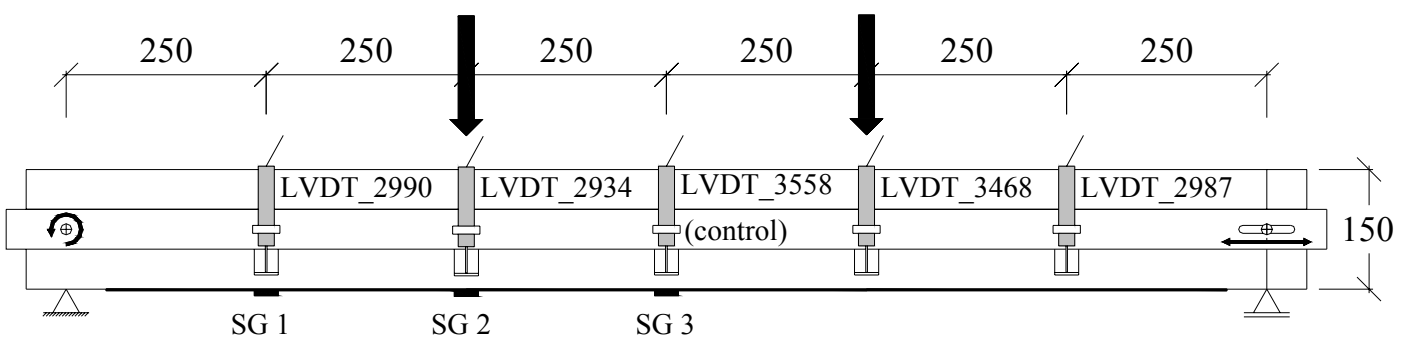

Figure 9. Measuring devices (LVDT - Linear Variable Displacement Transducer; SG - Strain Gauge; dimensions in $\mathrm{mm})$

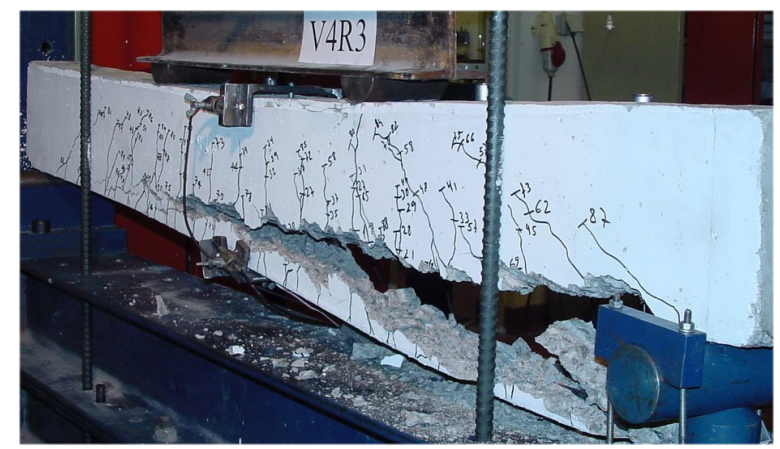

Figure 10. Typical failure mode of a strengthened beam after its failure (beam V4R3) 


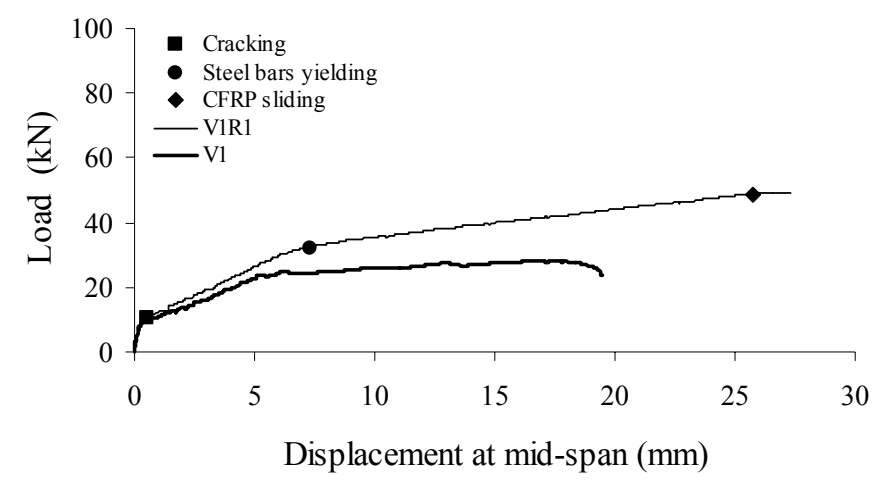

(a)

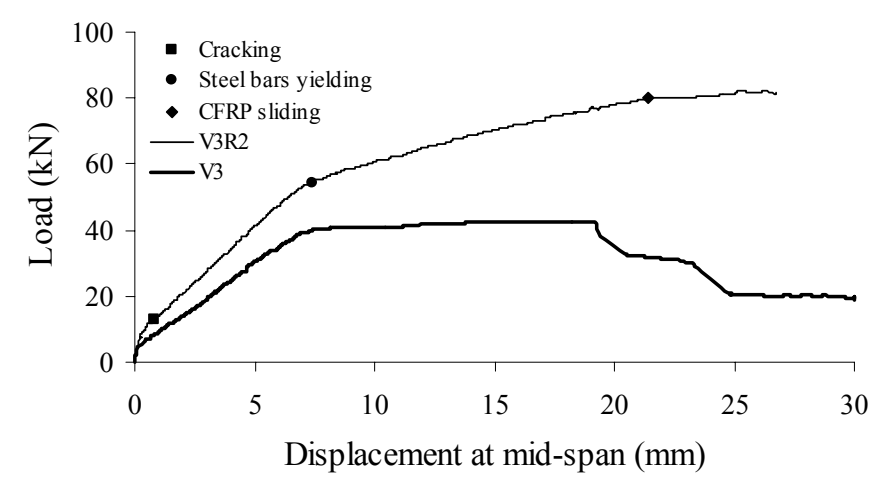

(c)

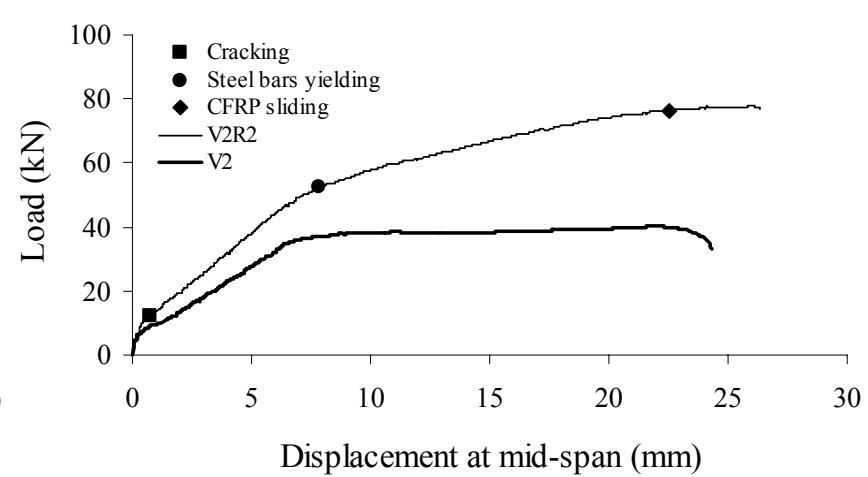

(b)

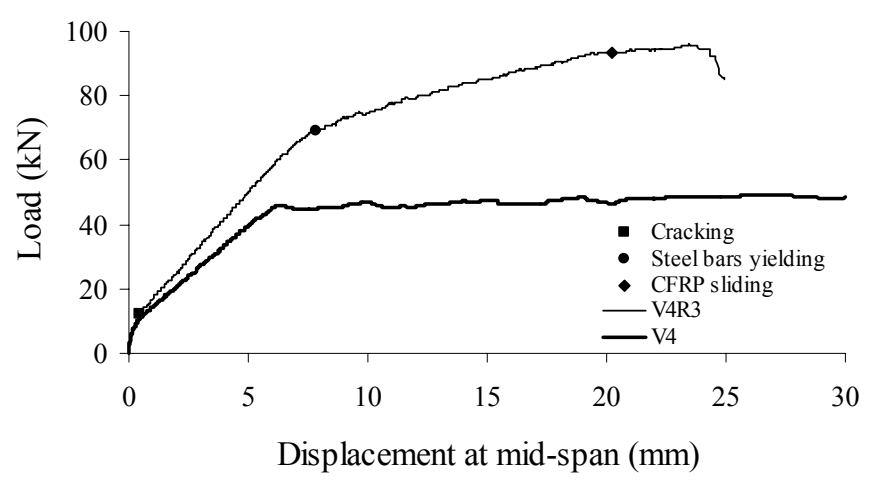

(d)

Figure 11. Force-deflection relationships of series: (a) S1, (b) S2, (c) S3 and (d) S4 


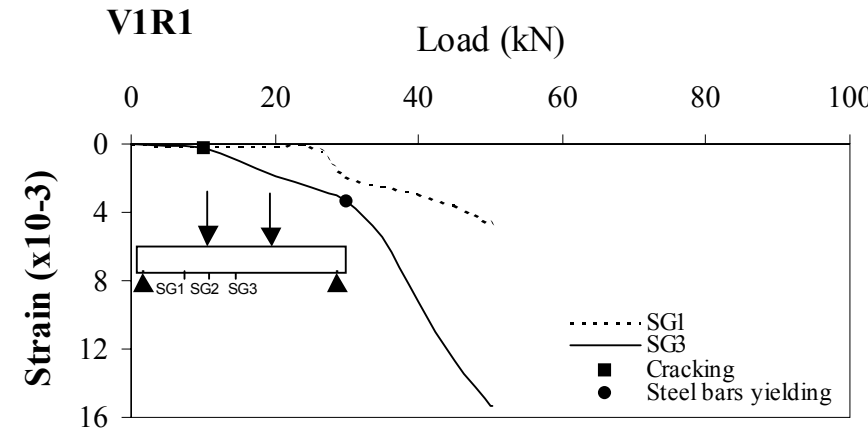

(a)

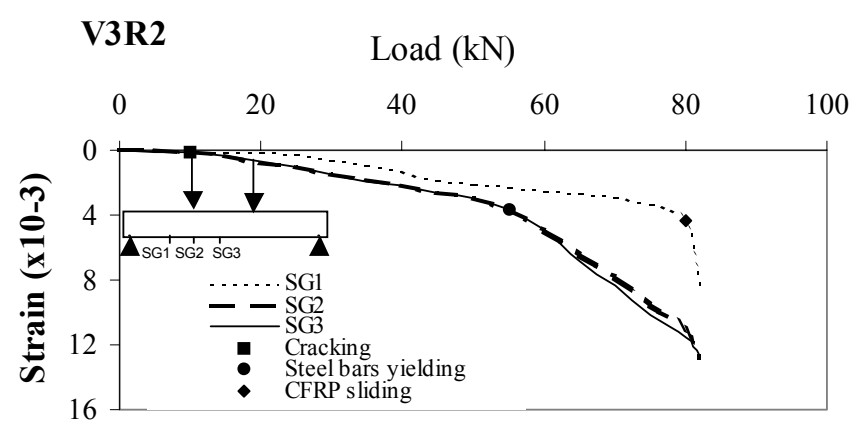

(c)

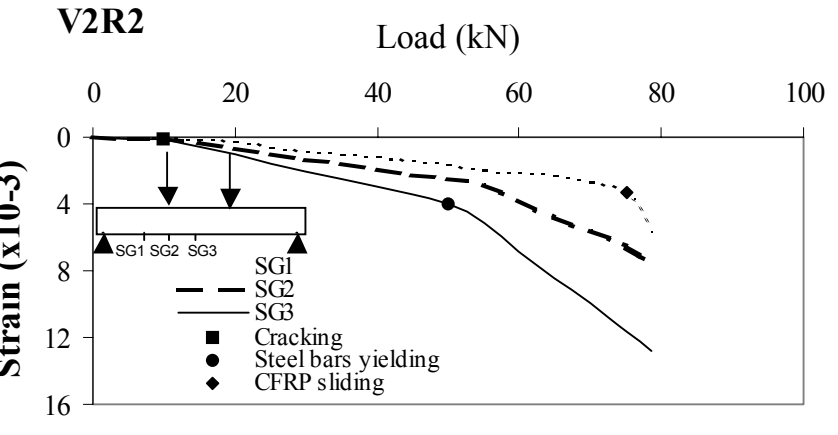

(b)

V4R3

$\operatorname{Load}(\mathrm{kN})$

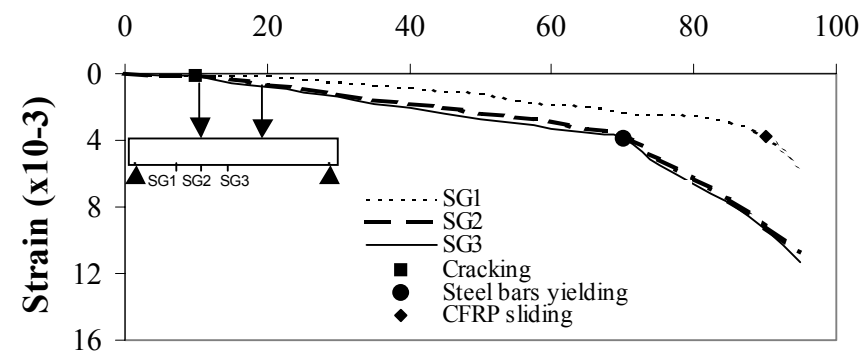

(d)

Figure 12. Force-strain relationships of series: (a) V1R1, (b) V2R2, (c) V3R2 and (d) V4R3 

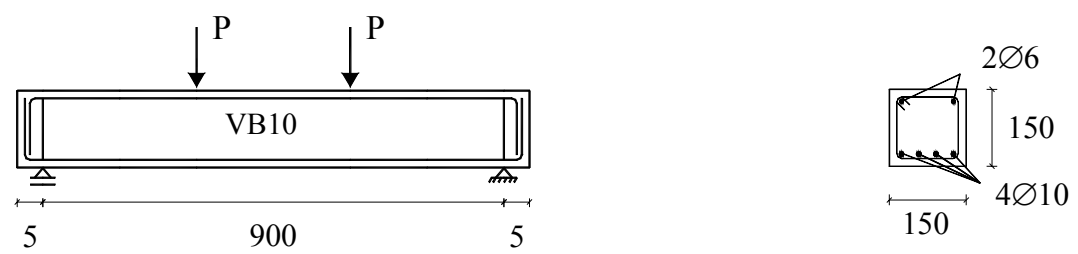

Cross section
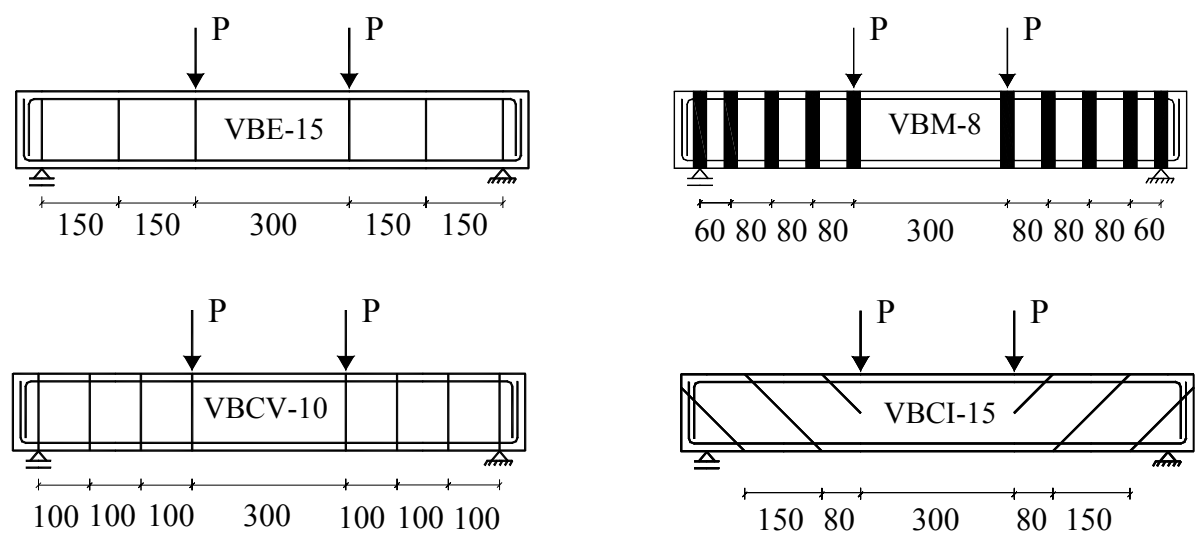

Figure 13. Series of beams failing in shear (dimensions in $\mathrm{mm}$ )

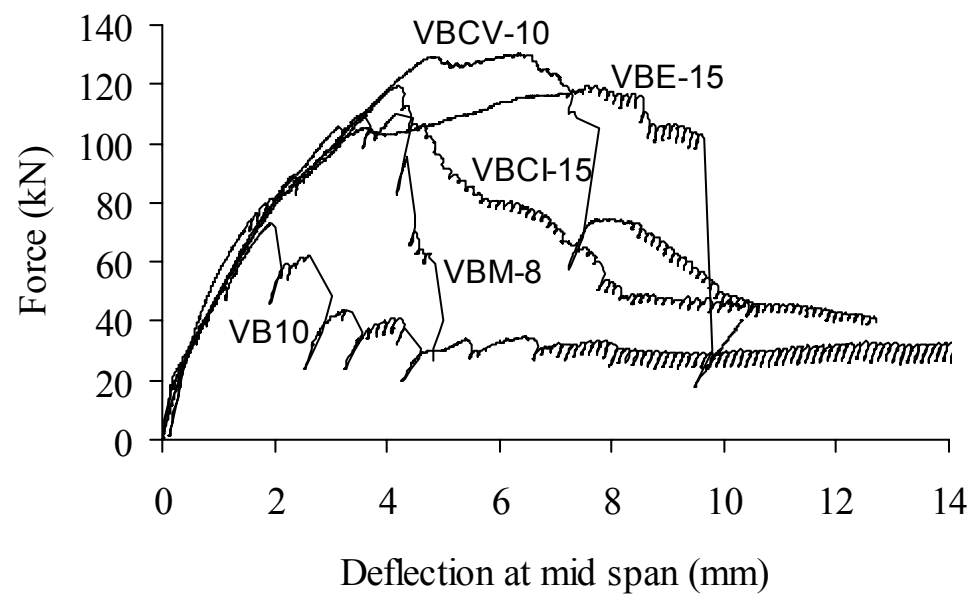

Figure 14. Relationship between the force and the deflection at mid span of the beams failing in shear 


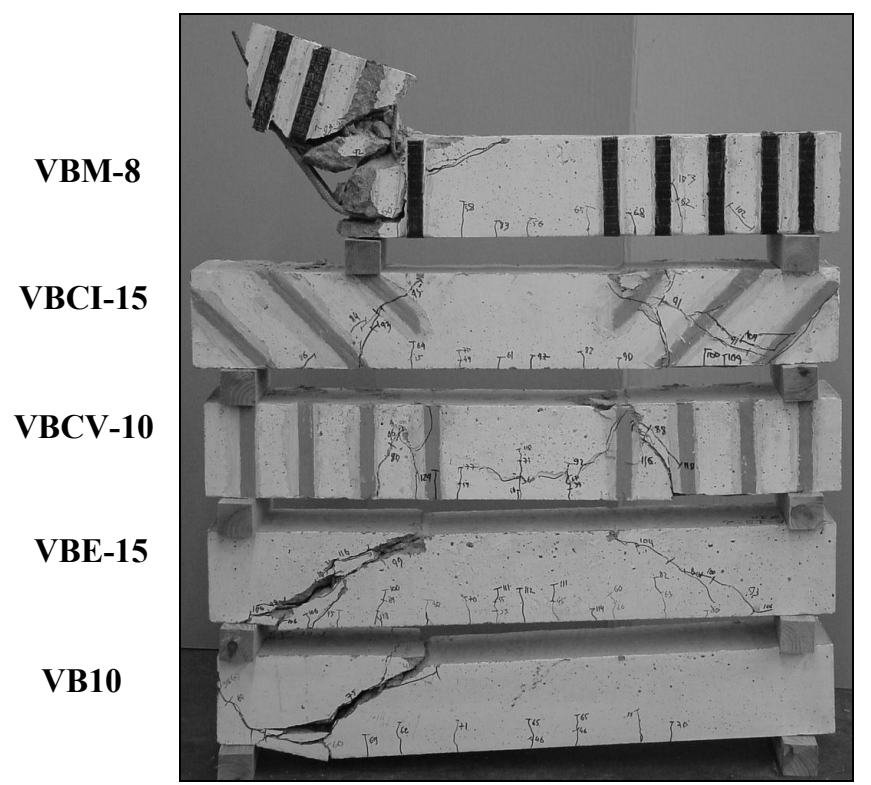

Figure 15. Appearance of the beams after have been tested

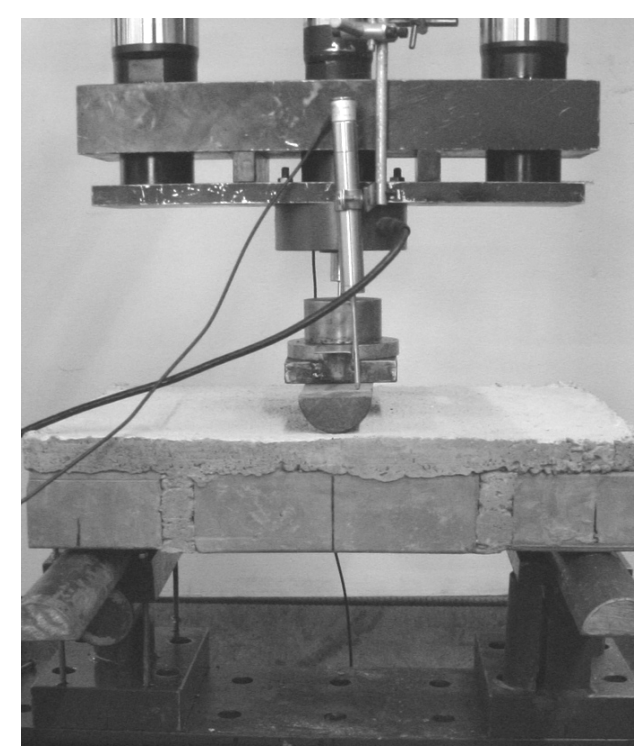

Figure 16. Test set-up of masonry panels 


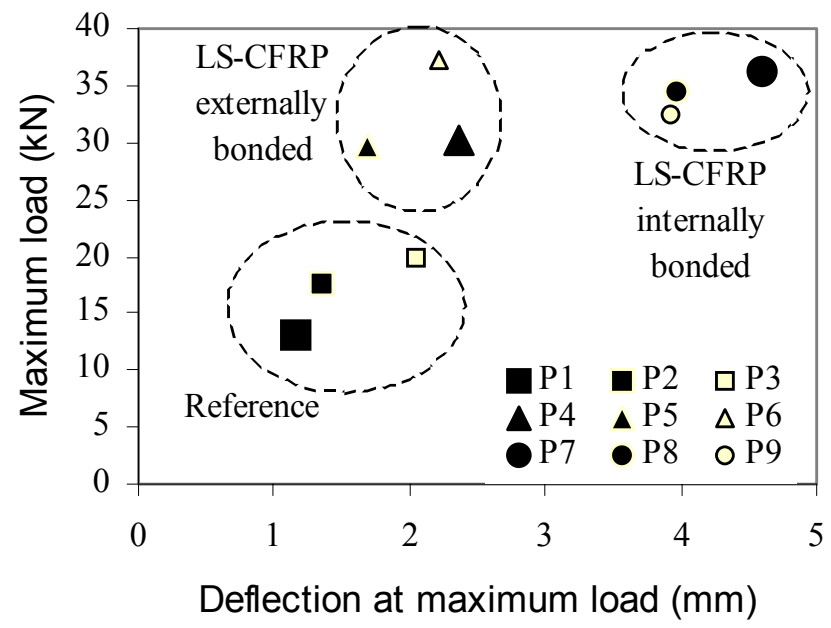

Figure 17. Maximum load and its corresponding deflection for the masonry panels 